\title{
The Polish power industry in energy transformation process
}

\author{
Lidia Gawlik ${ }^{1}$
}

Received: 31 August 2017 / Accepted: 1 November 2017 / Published online: 7 November 2017

(C) The Author(s) 2017. This article is an open access publication

\begin{abstract}
The article presents the present state of the electricity sector and the hard coal mining sector in Poland. Priorities for the future structure of electricity generation have been determined in the context of trends in the EU climate policy. Poland has significant reserves of coal, which will be used to produce electricity in order to secure the country's energy security and to make use of indigenous resources. Despite the current economic and financial difficulties of mining entities, the government has declared its support for hard coal mining industry. This is due to the fact that enormous investment outlays, exceeding the financial capabilities of the energy sector and the country, would be needed in order to fundamentally change the fuel structure of the sector. Due to the fact that coal-fired power plants, which now account for more than $46 \%$ of all power generation capacity, are deeply decapitalized and do not meet the EU emission requirements, the possibility of upgrading the existing units in order to improve their generation efficiency and extend their service life for the next several dozen years is explored. The Polish energy transition towards a low-carbon economy is largely based on energysaving ideas and efforts to increase the energy efficiency. There has also been a great increase in the production of renewable energy, especially wind power, which, however, is the reason for problems with the stability of power grids and the balance of supply and demand. The development of renewable energy sources used in local energy clusters is the
\end{abstract}

The work was done within the framework of statutory research of the Mineral and Energy Economy Research Institute, Polish Academy of Sciences.

Lidia Gawlik

lidia.gawlik@min-pan.krakow.pl

1 Mineral and Energy Economy Research Institute, Polish Academy of Sciences, 31-261, Krakow, Wybickiego 7A, Warsaw, Poland preferred option. The presented scenarios have not yet been confirmed in the official documents of the Polish government. The government faces the task of building the long-term energy policy and energy transformation strategy that should take into account internal and external determinants and priorities. At the same time, it is important to negotiate the path of development that is consistent with the direction of the changes proposed by the European Union and takes into account the capabilities of Poland.

Keywords Hard coal mining · The structure of electricity generation $\cdot$ Low carbon economy

\section{Introduction}

Energy transformation is linked to changes in the production and use of energy and is driven by progress. The coal was the basis for the industrial revolution in the eighteenth century. At the turn of the nineteenth and twentieth centuries, crude oil has contributed to the development of the automotive industry. Natural gas has proved to be a versatile raw material, not only in power industry, but also in the chemical industry, only after the Second World War. Nuclear power was introduced in the second half of the twentieth century. The last decade of the last century has started the process of dissemination of renewable energy. It is believed that this is the next stage in the global energy development.

In the light of global climate change and the limitation of non-renewable fossil fuel resources, sustainable development has to play an increasingly important role in securing energy needs, in which the necessities of the present generation must take into account the wellbeing of future generations. The energy and climate policy gradually implemented in the European Union is focused on the issue of emission reduction 
from, among others, the energy sector, while the energy transformation is often implemented (e.g. in Denmark, Germany, and France) by eliminating fossil fuels in favor of the power industry based on renewable energy sources. An additional argument for the development of renewable energy, besides limiting the impact of the traditional energy sector on the environment, is that renewable sources have a local character, help to diversify energy supplies, and strengthen the energy independence of the country (IEA 2016).

The concept of transformation is naturally associated with innovation and new technologies. An important element in making a change is not only the availability of technology but also the development of such an energy policy that will enable the relatively inexpensive (for the society to benefit from it) and least environmentally damaging uninterrupted energy supply (energy security).

In a broader sense, energy transformation is associated with the promotion of low-carbon energy sources based on lowcarbon and efficient (energy-efficient) energy production technologies. Another element of energy transformation is the development of energy-saving ideas, that is the improvement of energy efficiency in various sectors of industry and services (e.g., insulation and thermal efficiency improvement, energysaving lighting, cogeneration-combined heat and power generation, and energy recovery in industrial processes) (Mlynarski et al. 2017). Therefore, not only the energy supply in the right quantity and quality, but also the volume of demand that can be influenced are both of great importance.

The article presents the present state of the electricity sector and the hard coal mining sector in Poland. In the context of trends in the EU climate policy, the Polish energy economy, based on the generation of electricity from solid fuels, requires a deep transformation. An outline of the planned activities differs from the pathways adopted in other EU countries. This is due to the specific conditions of Poland.

\section{Comparison of electricity production systems European Union countries}

In $2014,48 \%$ of electricity produced in the European Union countries came from burning combustible fuels (such as gas, coal, and oil) while more than half came from emission-free sources: $27 \%$ from nuclear power and $25 \%$ from renewable energy sources. Among these renewable energy sources, the highest share of electricity came from hydropower plants (13\%), wind turbines (8\%) and solar power (3\%) (EC 2016b).

Poland was at sixth place as concerns the amount of electricity produced in the EU with about $5 \%$ share of total, after Germany (19.7\%), France (17.6\%), UK (10.6\%), Italy (8.7\%), and Spain $(8.6 \%)$ (Table 1).

The sources of electricity production vary among the Member States (Fig. 1): Estonia and Poland are the two countries with over $80 \%$ of electricity production from solid fuels. Statistical data from 2014 (EU 2016) show that Poland produced 129 TWh of electricity from coals while Germany with the share of production from solid fuels produced more than twice as much electricity (274 TWh) from coals. Combustible fuels dominate in the similar Polish percentage also in Malta, Estonia, Cyprus, but the amount of electricity produced was much smaller there. Over three quarters (77\%) of electricity production came from nuclear power plants in France, followed by 58\% in Slovakia and 54\% in Hungary. The highest share of renewable energy sources was in Austria (82.2\%) followed by Croatia (74.2\%): both countries with almost $70 \%$ of electricity produced from hydro power plants. High shares of renewable energy in the country's production structure of Portugal (61.4\%) and Denmark (55.9\%) came from wind energy (EC 2016b).

Out of 808.7 TWh produced from solid fuels in the EU countries, over $62 \%$ of solid fuel-based electricity came from three countries: Germany (33.9\%), Poland (16.0\%), and UK $(12.5 \%)$. Germany is also a leader in production of electricity from renewables. $18.1 \%$ of the total EU renewable electricity production came from Germany. Additionally, with over $11 \%$ of production in nuclear plants and high share from non-RES wastes Germany's electricity production structure is highly diversified and more sustainable than the Polish one. Looking at the shares of electricity production of the major EU producers, energy mix of Poland is unique.

\section{The situation of the Polish energy sector}

The Polish energy mix is unique in Europe because it is based on domestic solid energy resources (hard coal and lignite). Electricity consumption is characterized by a slight upward trend. The share of hard coal in electricity production, despite a downward trend, is still over 50\% (Table 2).

The structure of installed capacity in the domestic power system in the year 2016 is presented in Fig. 2. Out of $41.4 \mathrm{GW}$ of the total installed capacity, $32.4 \mathrm{GW}(78.3 \%)$ is installed in the commercial power industry, including $19.2 \mathrm{GW}$ in hard coal-fired power plants. The production structure changes are introduced slowly. In 2011, the share of professional solid-fuel power plants in the power structure of the National Power System was $79.7 \%$, which means that in 2016, this share has decreased by 10.9 percentage points to $68.8 \%$. With a $4 \mathrm{GW}$ increase in the total installed capacity, a $1.3 \mathrm{GW}$ decrease in the share of solid-fuel power plants is accompanied by an increase in the case of all other energy sources, especially wind power and other renewable sources, where a total 4.4 GW capacity increase was recorded.

Due to the extensive use of coal, the energy sector is characterized by high emissions. In addition, despite partial modernization, most of the existing production capacities are 
Table 1 Gross electricity generation in the European Union and leading electricity producers in 2014

\begin{tabular}{|c|c|c|c|c|c|c|c|}
\hline & \multirow{2}{*}{$\begin{array}{l}\text { Gross electricity } \\
\text { generation } \\
\text { TWh }\end{array}$} & \multicolumn{6}{|c|}{ Shares of particular energy sources, [\%] } \\
\hline & & $\begin{array}{l}\text { Solid } \\
\text { Fuels }\end{array}$ & Nuclear & Renewables & Gases & $\begin{array}{l}\text { Petroleum and } \\
\text { products }\end{array}$ & $\begin{array}{l}\text { Wastes } \\
\text { non-RES }\end{array}$ \\
\hline EU 28 & 3190.7 & 25.3 & 27.5 & 29.2 & 15.4 & 1.8 & 0.7 \\
\hline Germany & 627.8 & 43.7 & 15.5 & 26.8 & 11.6 & 0.9 & 1.2 \\
\hline France & 562.8 & 1.7 & 77.6 & 17.3 & 2.7 & 0.3 & 0.4 \\
\hline UK & 338.9 & 29.8 & 18.8 & 19.9 & 30.0 & 0.5 & 1.0 \\
\hline Italy & 279.8 & 15.5 & 0.0 & 43.7 & 34.6 & 5.1 & 0.9 \\
\hline Spain & 278.8 & 15.7 & 20.6 & 40.9 & 17.5 & 5.1 & 0.2 \\
\hline Poland & 159.1 & 81.4 & 0.0 & 12.8 & 4.6 & 1.0 & 0.0 \\
\hline Sweden & 153.7 & 0.4 & 42.2 & 55.9 & 0.5 & 0.2 & 0.8 \\
\hline
\end{tabular}

Source: own elaboration based on EU (2016) obsolete units with low efficiency. The age structure of boilers and turbosets used in power plants is highly variable, while many of them are already over 30 years old (Szczerbowski 2016). According to a government document from 2009 (PEP 2009), in the perspective of 2030 , almost $15 \mathrm{GW}$ of the capacity installed in the power system should be decommissioned, while almost $6 \mathrm{GW}$ should undergo a deep modernization. Assuming an inevitable increase in electricity demand, it is estimated that the required new investments in the system should amount to $25.9 \mathrm{GW}$ (Duda et al. 2014). The need to replace and upgrade such a significant part of the power generation units is, on the one hand, a chance for qualitative changes, but, on the other, is associated with huge investment needs.

For several years, the lack of current energy policy of Poland can be observed. The last government document was published in 2009 and includes an action plan covering the period up to 2030 (PEP 2009). This document assumes the diversification of the fuel mix of the power industry through, inter alia, the development of nuclear power. For various reasons, there have been significant delays in the implementation of the program. In addition, the development of the EU energy and climate policy and the government change in Poland make it necessary to redesign the energy policy of the country until 2050. Current investments in the power sector include the construction of several new coal-fired units (Kozienice$1075 \mathrm{MW}$, Opole - $2 \times 900 \mathrm{MW}$, and Jaworzno III$910 \mathrm{MW}$ ), which means continuing to use domestic coal to meet the country's energy needs. However, no long-term action plan was implemented.

The main argument in favor of coal based power industry is the energy security of Poland, as the coal resources (both hard coal and lignite) are abundant, and the well-developed coal mining industry currently employs nearly 100,000 people.

\section{The situation in the hard coal mining sector}

Coal has always been an important energy source in Poland. In the market economy (after the change of political system in Poland), the coal industry turned out to be unsuited to competition. Hence, in the entire period since 1989, a continuous
Fig. 1 Production of electricity by source in the EU countries, \%. Source: own elaboration based on EU (2016)

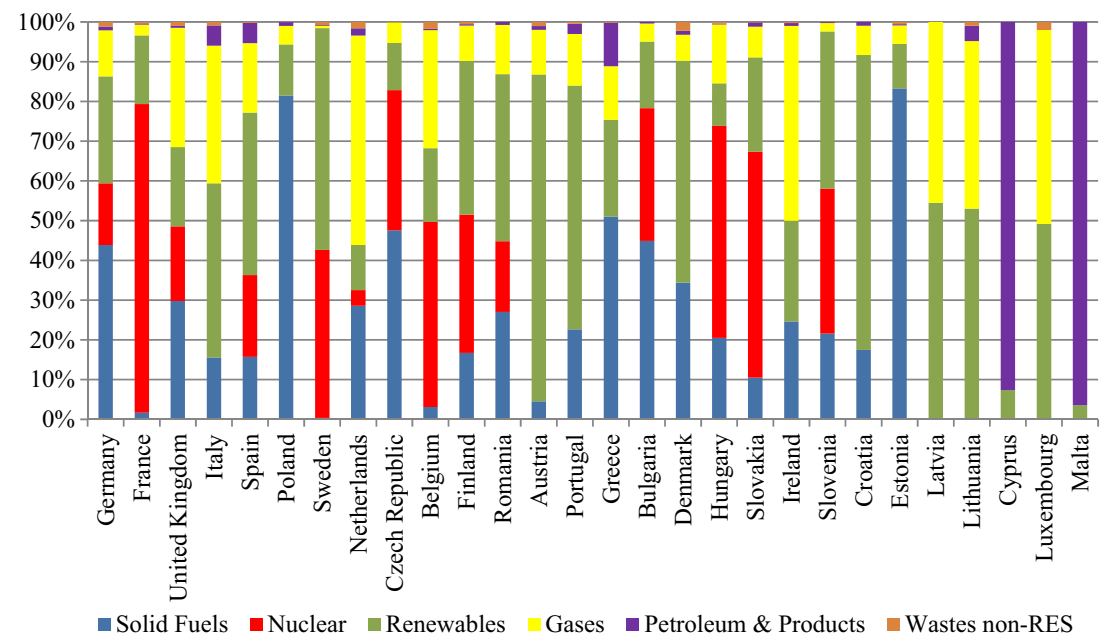


Table 2 The structure of electricity production in domestic power plants, the volume of electricity exchange with foreign countries, and the energy consumption in Poland in 2011 and 2016, GWh

\begin{tabular}{lllll}
\hline No. & Item & 2011 & 2016 & Dynamics, \% \\
\hline 1. & Total production & 163,153 & 162,626 & -0.32 \\
1.1 & Commercial power plants & 151,319 & 140,727 & -7.00 \\
1.1 .1 & Commercial hydropower plants & 2529 & 2399 & -5.14 \\
1.1 .2 & Commercial thermal power plants & 148,790 & 138,328 & -7.03 \\
1.1 .2 .1 & Hard coal power plants & 90,811 & 81,348 & -10.42 \\
1.1 .2 .2 & Lignite power plants & 53,623 & 51,204 & -4.51 \\
1.1 .2 .3 & Gas power plants & 4355 & 5776 & 32.63 \\
1.2 & Other renewable power plants & 35 & 146 & 317.14 \\
1.3 & Wind power & 2798 & 11,623 & 315.40 \\
1.4 & Industrial autoproducers & 9000 & 10,130 & 12.56 \\
2. & The foreign exchange balance & -5243 & 1999 & -138.13 \\
3. & The domestic electricity consumption & 157,910 & 164,625 & 4.25 \\
\hline
\end{tabular}

Source: PSE (2017) restructuring of the sector is taking place. Poland has large coal reserves - at the current level of production, the reserves should last for 153 years (Szuflicki et al. 2017). At the same time, the domestic demand for coal is decreasing (Table 3). Over the 5 years, the consumption of coal has decreased by 14 million tons; while the downward trend applies to all sectors of the economy, the largest decrease in the use of coal has been reported in heat engineering $(23.4 \%)$ and other market segments $(26.2 \%)$ including the industry, agriculture, and households.

As a result of lower consumption, the domestic market of Polish steam coal producers has shrunk. The domestic demand was partially met by imported coal, which effectively competed on the Polish market.

In the second decade of the twenty-first century, the overproduction and low prices on the international coal market can be observed. The reason is the increase in production of coal accompanied by a decrease in demand for this raw material due to slowing down the pace of development in countries that are major users and importers of coal. As a result, the coal prices in 2016 year were lower than those observed between 2008 and 2009 during the global financial crisis. In 2015, the

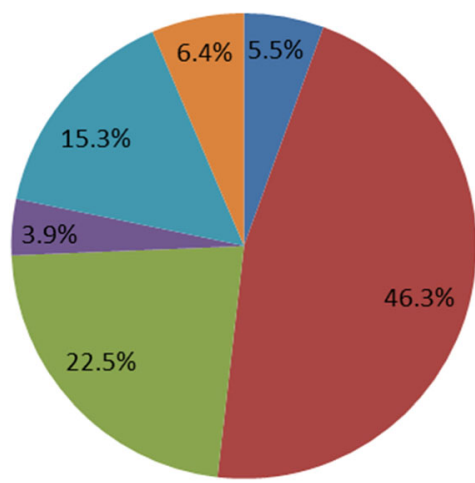

Commercial hydropower
plants
Commercial hard coal
fired power plants
Commercial lignite fired
power plants
Commercial gas power
plants
Wind and other RES
power plants
Industrial autoproducers

Fig. 2 The structure of installed capacity in the domestic power system. Source: Report (2016) worldwide coal production has dropped by $3.5 \%$ but was $6 \%$ higher than in 2010, while the global steam coal trade has decreased by about $8 \%$. Coal prices have been on a downward trend for the fifth year in a row. In 2015, they decreased by $21 \%$ compared to the average of the previous financial year (Lorenz and Ozga-Blaschke 2016).

This had a major impact on the economic efficiency of Polish producers of this raw material (Fig. 3). Since 2012, a rapid decrease in the demand for steam coal can be observed. In the previous years, with improving financial results related to a rapid increase in the selling prices of coal mining companies, coal production costs were also increasing. However, the rate of increase in costs has not been slowed even after the rapid drop in prices and sales volume. Once again, the Polish mining industry was on the verge of bankruptcy.

The government has taken steps to save a number of coal mines. Although the official program for the coal industry has not yet been announced, organizational and ownership changes in mining entities were carried out.

The changes included the consolidation of all Upper Silesian coal mines that produce steam coal, with the exception of a few mines owned by the energy companies, into a single state-owned entity. Mines or parts of mines that are considered to be permanently unprofitable are to be closed.

In 2016, although a slight improvement was observed, the overall financial performance remained negative.

The aim of further restructuring efforts is to achieve sustainable economic efficiency of the sector and to maintain rational use of the existing internal potential of coal mining, including: resource, social, and economic potential. It is obvious that hard coal mining in Poland has the potential for development (strengths), but a number of features (weaknesses) limit the ability to effectively achieve goals and success (Gawlik 2017). The declaration of government support and the government's favorable policy based on the conviction that the energy security of Poland can be strengthened by 
Table 3 The consumption of steam coal in the domestic market in the years 2010-2015, thousand tons

\begin{tabular}{|c|c|c|c|c|c|c|c|}
\hline Item & & 2010 & 2011 & 2012 & 2013 & 2014 & 2015 \\
\hline Power coal & & 72.452 & 71.623 & 64.443 & 66.185 & 61.008 & 58.464 \\
\hline \multirow[t]{4}{*}{ Including: } & $\begin{array}{l}\text { Commercial power plants and } \\
\text { CHP plants }\end{array}$ & 44.134 & 43.450 & 40.059 & 40.364 & 37.120 & 37.450 \\
\hline & $\begin{array}{l}\text { Industrial and municipal heating } \\
\text { plants }\end{array}$ & 4.319 & 3.718 & 3.808 & 3.750 & 3.373 & 3.308 \\
\hline & $\begin{array}{l}\text { Other market segments } \\
\text { consuming steam coal }\end{array}$ & 23.999 & 24.455 & 20.576 & 22.071 & 20.515 & 17.706 \\
\hline & Including: $\quad$ Households & 11.900 & 10.640 & 11.020 & 11.076 & 9.900 & 9.750 \\
\hline
\end{tabular}

Source: own work based on Central Statistical Office of Poland (GUS 2009-2016) and Industrial Development Agency (ARE 2009-2016) the use of indigenous resources is essential for achieving this objective.

The greatest threat to the future of coal mining in Poland is the long-term climate change policy of the European Union set out in the Roadmap for moving to a competitive low carbon economy in 2050. (EC 2011a), Energy Roadmap 2050 (EP 2013), and in WHITE PAPER Roadmap to a Single European Transport Area (EC 2011b).

The consistently implemented EU policy towards reducing greenhouse gas emissions is targeted at fossil fuels, especially solid fuels (hard coal and lignite), as those associated with high emissions. In the so-called "Winter Package" (EC 2016a) the European Commission proposes changes to reorganize the electricity market, revisions to the Renewable Energy Directive and Energy Efficiency, and a $\mathrm{CO}_{2}$ limit of $550 \mathrm{~g}$ of $\mathrm{CO}_{2}$ per kilowatt hour for power plants, which would exclude coal-fired power plants from CAT mechanism eligibility.

The prospects for the development of coal market are unfavorable due to the increasing competitiveness of other energy carriers on both domestic and foreign electricity markets. The tightening of environmental standards is slowly becoming a fact, and this means that an increase in $\mathrm{CO}_{2}$ emission charges is expected, which will affect the coal power industry.

For the consolidated mining industry, it is essential to determine the possible long-term demand for coal. The ability to

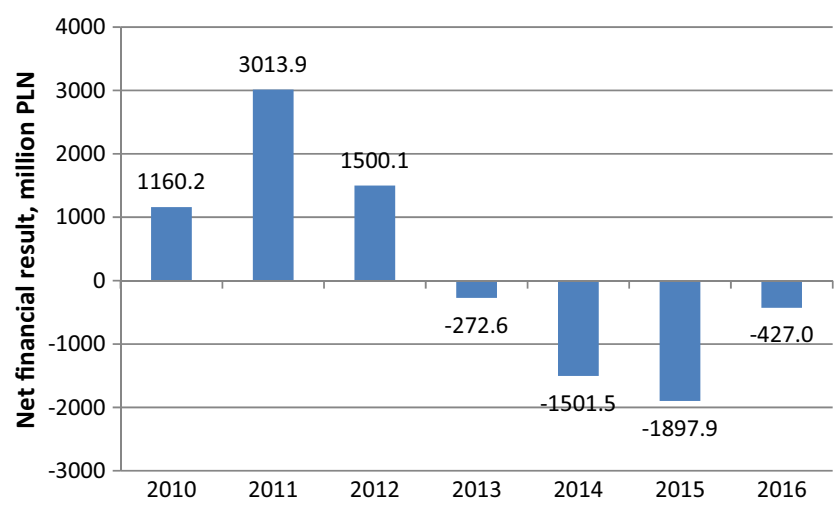

Fig. 3 The net financial result of the hard coal mining industry in the years 2010-2016. Source: own work based on data from the Industrial Development Agency (ARP 2017) sell coal in the domestic market is decisive for determining the size of the industry and for evaluating the restructuring efforts. The sales of steam coal offered by Polish producers in the domestic market have significantly decreased from around 63-65 million tons in 2007-2008 to 60.8 million tons in 2011 and around 53-54 million tons in 2015 and 2016. Compared to 2008, the sales of coal in the domestic market in 2016 have decreased by 14\%; the decline affected particularly the commercial power industry, where it exceeded $23 \%$ (ARP 2016).

The reduced consumption of coal in the Polish economy is clearly visible. It is estimated (Project 2017) that the demand for hard coal in Poland in 2030 may be $20 \%$ lower than in 2015 unless measures aimed at strengthening the role of coal in the domestic market are taken.

The decrease in the use of coal in other, besides the power industry, segments of the coal market is inevitable. Approximately $50 \%$ of the demand for heat is met by district heating, while the primary fuel used to produce heat is hard coal. The future position of district heating is influenced by the EU energy and climate legislation. The heating sector is committed to taking measures to improve the energy efficiency of energy processes, increase the share of renewable energy sources, and reduce pollution, mainly air pollution. District heating companies must be prepared for $\mathrm{EU}$ regulations on industrial emissions. They impose $\mathrm{SO}_{2}, \mathrm{NO}_{\mathrm{x}}$ and dust emission limits (IED 2010), which will take effect from 2025 and exclude units not complying with the new regulations in this area. The restrictions also apply to combustion plants with a rated thermal input of 1 to $50 \mathrm{MW}$ (MCP 2015). The national support system includes the generation of heat in highefficiency cogeneration, which means that heat production in commercial and industrial heating plants will be reduced. The pace of moving away from coal will depend on investment opportunities in the power industry (cogeneration), the possibility of substitution of coal fuel in the heating system, and the development of thermal insulation and energy-saving ideas.

In other sectors of the economy, coal is mainly used in households. The problems associated with low-stack emissions are the dominant element forcing the move away from traditional coal-fired boilers used for space heating. The 
furnaces will be replaced by high-efficiency coal furnaces or furnaces using other fuels, while the more and more popular thermal efficiency improvement and passive and energyefficient buildings will also contribute to reducing the use of coal.

These already established trends are the reason why the volume of the domestic demand for coal has become, and will be even more, dependent on the development model of the commercial power industry in the future. There are several good premises for the mining industry, including the question of energy security, which should affect decisions on the model and coal-dominated fuel mix of the commercial power industry.

\section{The model of commercial energy sector}

As already mentioned, the installed capacity in Poland will have to be systematically replaced due to the age of power plants and technologies that make it impossible to meet emission standards. Decommissioning of obsolete units may be further accelerated due to environmental standards imposed on the sector through the implementation of the Directive on Industrial Emissions - IED (2010), and the related restrictions resulting from the detailed Best Available Techniques conclusions (BAT 2016) adopted by the European Commission in August 2017.

It is obvious that, despite the energy-saving measures, the development without an increase in demand for electricity would not be possible in Poland. An example of this is the launch of processes aimed the development of the electric vehicle market, which will increase the demand for electricity over the next 20-30 years and thus will result in the need to increase the currently installed capacity.

The question is what are the new technologies to be phased in? The current government bases its strategy on linking coalfired power generation with the construction of new largescale coal-fired plants, which, thanks to long-term contracts with Polish mines, will ensure an outlet for Polish coal. It is also emphasized that the new energy facilities will have a high efficiency of up to $46 \%$.

The basic argument is the energy security. Diversification towards increase the share of natural gas in the energy mix is seen in many countries as a transitional step towards a lowcarbon energy sector. Under Polish conditions development of gas sources means the need to increase imports. Domestic natural gas production, i.e., 5.1 billion $\mathrm{m}^{3}$ in 2016, accounts for about $12 \%$ of the total consumption of this raw material in the economy of the country (GUS 2016), the rest is imported mainly from the east. The high import prices of this raw material limit the effectiveness of its use in the power sector, and the dependence on one supplier (Gazprom) poses a threat to their reliability. Partial diversification of supplies was achieved by putting into operation in 2016 an LNG terminal with a regasification capacity of 5 billion $\mathrm{m}^{3}$. There are plans to expand its capacity to $7.5 \mathrm{~m}^{3}$. Further projects include the construction of the Baltic Pipe, which will supply natural gas from Norway to Poland. These investments, however, require time and at the earliest in 2022, when the long-term gas supply agreement from Russia will expire, it will be possible to talk about safe and diversified import opportunities for this raw material.

Energy transformation through the development of wind power has recently been slowed down by wind farm location constraints (Act 2016a) and a reduction of subsidies for energy production from renewable sources (Act 2016b). Renewable energy sources will be deployed as demonstrating the economic efficiency and if they find funding.

Still, no decision regarding the construction of nuclear power plants with a total capacity of $6000 \mathrm{MW}$ has been taken. At the same time, substantial costs of such investments and the unfavorable public perception of nuclear energy are being pointed out.

Therefore, Poland has to focus on coal. Both the development of the power industry and the restoration of the efficiency of hard coal mining require a lot of financial resources; however, the question is whether to invest in the development of mining or to invest even more money in decommissioning of mining operations and create a huge social problem related to the unemployment of miners.

It is obvious that the move away from coal within 10 or even 20 years is not possible. However, there are ongoing efforts aimed at finding alternatives to the development of capacity based on coal, although the demand for electricity will increase due to the growing demand for cooling and heating services and the expected emergence of electric cars.

One of the ideas is the modernization of the existing coalfired power units with a capacity of $200 \mathrm{MW}$ (ME 2016). One of the following solutions should be used for the selected units in order to improve the efficiency and reduce the $\mathrm{CO}_{2}$ emissions of the system:

- A combination of two modernized boilers with one turboset and the development of a $500 \mathrm{MW}$ unit of higher efficiency and a lower technical minimum (at about 20\% of rated power),

- The pre-gasification of coal slurry (coal sludge) or municipal waste as an additional power supply for the unit,

- Conversion of coal-fired units into biomass-fired units,

- The use of oxy-combustion with $\mathrm{CO}_{2}$ capture, e.g. for the purposes of supporting oil and gas extraction. This would reduce emissions by as much as $80 \%$.

The efficiency of such units would be 2-3 percentage points lower than the new ones, but it was estimated that the cost of such upgrades would be significantly lower than the 
construction of new units with the same total capacity. Another advantage is the fact that these upgrades can be made by Polish companies, while the development of new units would require the import of technology. The discussed modernization would mean the continuation of the use of coal for about the next 20 years, while the construction of new coalfired units would result in the next 40 years of coal based power industry in Poland. Shorter service life of a power plant is paradoxically an asset rather than a burden, also when taking into account negotiations with the European Union.

Another important area is cogeneration. An emphasis was placed on cogeneration using hard coal, including the partial shift from commercial and industrial heating plants towards the commercial power industry. Polish heating plant operators argue that it is possible to add $7000 \mathrm{MW}$ to the Polish power system by switching the current heating capacity to cogeneration capacity. This applies to both large and small (including local) sources (Biznesalert 2017).

Such a solution would allow highly efficient use of coal and gas, which would translate into lower emissions. At the same time, the district heating targeted at a larger customer group means partial elimination of low-stack emissions in the household sector. The scale of possible changes is shown by the following figures: in 2015, the share of hard coal in the heat generated by the licensed heating companies was $73 \%$; in the case of cogeneration, the share of heat produced from hard coal was $81 \%$. The consumption of coal for heat production amounted to 13.5 million tons (ERO 2016).

It should be noted that, although a lot remains to be done to reduce emissions from the production of electricity, power plants and combined heat and power plants systematically reduce the emission of pollutants into the environment (Table 4).

\section{Possible models of distributed generation}

The planned development of distributed generation, based on renewable energy sources, will serve to supplement large coalfired units. In small towns and in rural areas, it is planned to develop agricultural biogas plants, working independently or as support for unstable wind power. Biomass boilers can play a similar role. These local, sustainable energy sources will allow coping with blackouts that are prevalent in underdeveloped areas. In cities - biogas is obtained from sewage waste or as a result of gasification of organic parts of municipal waste and can be used for the production of electricity or System Heat, especially in high-efficiency cogeneration.

Land-based wind turbines are not currently supported because of their unstable operation and the resulting problems with energy balance in the national power grid, but the installed capacity will gradually increase. Increasingly lower investment costs lead to the development of photovoltaic
Table 4 Emission of environmental pollution from commercial energy sector-comparison of the 2013 and 2016 year

\begin{tabular}{lllll}
\hline \multirow{2}{*}{ Kind of emission } & 2013 & 2016 & Change \\
\cline { 3 - 5 } & \multicolumn{2}{l}{ Thousand tons } & & $\%$ \\
\hline $\mathrm{CO}_{2}$ & 146,947 & 140,181 & 6766 & 4,6 \\
$\mathrm{SO}_{2}$ & 304,141 & 162,779 & 141,362 & 46,5 \\
$\mathrm{NO}_{x}$ & 205,538 & 150,581 & 54,957 & 26,7 \\
Fly ash & 15,847 & 10,934 & 4913 & 31,0 \\
\hline
\end{tabular}

Source: ARE (2017)

systems by prosumers that is customers who produce electricity primarily for their own needs; however, the inclusion of photovoltaic plants into the national power grid is also discussed in light of the growing demand for energy for cooling during the summer months.

In addition, the concept of local energy clusters has also emerged. These are agreements between entities offering services in the area of production, distribution, storage, and supply of energy and fuels in the local area. The aim is to increase the energy security of regions while maintaining economic viability and sustainable development. The main objective is to balance the needs of the local community and the potential for the development of distributed energy sources, including prosumer sources. The task is to stimulate local communities to cooperate and generate renewable energy for their own needs and in order to distribute it locally to medium voltage networks.

An important element of this concept is using local renewable energy resources in coordinated way with a current demand. This will reduce the cluster's demand for energy from the National Power Grid and decrease the demand for supply of transmission services in high-voltage networks. It is possible to use local renewable resources, such as solid waste biomass, which can be used to heat homes and small utilities, or to recycle industrial and municipal waste through thermal treatment, which will also improve the quality of the environment. Apart from limiting the demand for fossil fuels, mainly coal, the cluster economy will help to reduce emissions, increase energy efficiency, and reduce the cost of supplying the region with electricity and heat. On the local scale, it is possible to improve the quality of power, mainly by the reduction of voltage drop and phase deformation, thus increasing the utility values of electricity. Local energy production will lead to the reduction of transmission capacity, and the improvement of quality can affect also neighboring regions.

It is not without significance to stimulate economic development outside the areas of larger agglomerations. On the national scale, this is primarily to build energy security for less urbanized areas and to more independent from external supplies of raw materials and energy. 
In the concept of economy transformation, more and more emphasis is placed on research and development activities and the creation of innovative solutions in the area of clean coal technology. The economic priorities in the mentioned R\&D activities and innovative solutions include the National Smart Specializations on sustainable energy.

In the longer term, the coal-based power industry will be supplemented by renewable energy sources, possibly stable or supported by energy storage (e.g., P2G technology). In the field of nuclear power, the construction of small modular nuclear reactors (SMRs) in the years 2035-2040, which would replace the obsolete coal-fired power plants (200 MW, which are currently planned to be included in the revitalization program) (ME 2016). The advantage of such a solution is the fact that the size and modular structure of these reactors allows them to replace the production capacity of obsolete units when needed and to spread the investment costs over time. In addition, they can be located in different parts of the country, creating a more distributed grid than in the case of the construction of large power plants.

\section{Conclusions}

The presented directions of hard coal mining and energy development are based on statements by government representatives and fragmentary studies. They have not yet been confirmed in the official documents of the Polish government.

There is no officially known program for hard coal mining and although the measures taken and the improvement in the global coal markets have contributed to a gradual improvement in the financial performance of the industry, it is difficult to assess whether the mentioned actions are sufficient for a long-term financial efficiency of the mining sector. The direction aimed at linking the coal mining industry with the power sector has its implications in determining the energy sector development path. This, in turn, is in contradiction with the EU's objective to achieve the goals of a low carbon economy in the perspective of 2050. The path followed by Poland is longer and more difficult. While meeting the requirements of the energy and climate package by 2020 seems not to be threatened $(3 \times 20 \times 20-\mathrm{a} 20 \%$ reduction of greenhouse gas emissions, a $20 \%$ increase in the share of renewable energy sources (RES) in energy production, and a $20 \%$ increase of the energy efficiency), the objectives set out by the European Union for the year 2030 and, especially, 2050 are difficult to accomplish for Poland. This stems from the historically conditioned dependence of the Polish economy on coal. Reconstruction in the direction of transformation, understood as the elimination of fossil fuels and replacing them with zeroemission sources, does not meet the conditions of sustainable development of the country. There are not enough investment funds, while the mentioned reconstruction leads to irrational, often irreversible, waste of own resources, and reduces the energy security of the country. In addition, such transformation is related to the need to incur huge financial costs of the development of power industry (including transmission infrastructure). In addition, substantial funds would be required for the liquidation of the mining industry (hard coal and lignite) and to cope with social problems in former mining regions.

The model of change presented here extends the possibilities of using coal in the power industry and at the same time:

- Reduces emissions from the energy system. Thus, the Polish way of energy transformation implementation is aimed at reducing the environmental burden despite limited investment resources.

- Is in line with the doctrine of the energy security of the country thanks to the use of own primary energy carriers,

- Results in the decentralization of the national energy system, which would be based on smaller units spread across the country.

In further transformation efforts, Poland has to continue to rely on coal (at least for the time being) while improving the efficiency of power units by investing in the technological process of coal combustion and thereby reducing carbon dioxide emissions. At the same time, there is a need to develop new sources of low-carbon energy, green industry, and distributed energy. Poland has to continue the efforts towards lowcarbon economy, while the development of advanced technologies reducing $\mathrm{CO}_{2}$ emissions and improving the energy efficiency is the right course of action.

The government faces the task of building the long-term energy policy and energy transformation strategy that will take into account internal and external determinants and priorities. At the same time, it is important to negotiate the path of development - consistent with the direction of the changes proposed by the European Union but that would take into account the capabilities of Poland.

Open Access This article is distributed under the terms of the Creative Commons Attribution 4.0 International License (http:// creativecommons.org/licenses/by/4.0/), which permits unrestricted use, distribution, and reproduction in any medium, provided you give appropriate credit to the original author(s) and the source, provide a link to the Creative Commons license, and indicate if changes were made.

\section{References}

Act (2016a) Act of 20 May 2016 on investments in wind power plants. (Polish Journal of Laws 2016.961)

Act (2016b) Act of 22 June 2016 amending the Act on Renewable Energy Sources and certain other acts (Polish Journal of Laws 2016.925) 
ARE (2009-2016) Statistics of Polish Power Engineering (Statystyka Elektroenergetyki Polskiej) ARE (Agencja Rynku Energii SA), Warsaw, issues from years 2009-2016

ARE (2017) Emitor 2016. Emission of environmental pollution in power plants and combined heat and power plants (Emitor 2016. Emisja zanieczyszczeń środowiska $w$ elektrowniach i elektrociepłowniach zawodowych) ARE (Agencja Rynku Energii SA), Warsaw

ARP (2016) Basic information about the coal market and the hard coal sector in Poland in 2015. (Podstawowe informacje o rynku oraz. sektorze wegla kamiennego $w$ Polsce w 2015 roku) ARP (Industrial Development Agency), Katowice

ARP (2017) Industry Development Agency (Agencja Rozwoju Przemysłu SA) https://katowice.arp.pl/o-nas. Accessed 31 May 2017

BAT (2016) Best available techniques (BAT) reference document for large combustion plants. Institute for Prospective Technological Studies and Sustainable Production and Consumption Unit European IPPC. Bureau Final Draft

Biznesalert (2017) Why should Poland enter the path of energy transformation? (ANALYSIS) 2003.2017. http://biznesalert.pl/dlaczegopolska-wejsc-droge-transformacji-energetycznej-analiza/. Accessed 25 Aug 2017

Duda M, Gabryś HL, Kowalski M, Malko J, Kamrat W (2014) Experiences and challenges of the energy market (Doświadczenia $\mathrm{i}$ wyzwania rynku energii) Thematic issue. XX Science and Technology Conference REE. Kazimierz Dolny, 21-23 May: 5-42

EC (2011a) A Roadmap for moving to a competitive low carbon economy in 2050. Communication from the Commission to the European Parliament, the Council, the European Economic and Social Committee and the Committee of the Regions. European Commission, Brussels, 8.3.2011 COM(2011) 112 final. http:// www.europarl.europa.eu/meetdocs/2009 2014/documents/com/ com_com(2011)0112_/com_com(2011)0112_en.pdf. Accessed 23 Aug 2017

EC (2011b) White Paper. Roadmap to a single European transport areatowards a competitive and resource efficient transport system. European Commission, Brussels, 28.3.2011 COM(2011) 144 final. http://eur-lex.europa.eu/LexUriServ/LexUriServ.do?uri=COM: 2011:0144:FIN:en:PDF. Accessed 23 Aug 2017

EC (2016a) Clean energy for all Europeans - unlocking Europe's growth potential. European Commission - Press release Brussels, 30 November 2016. http://europa.eu/rapid/press-release_IP-16-4009 en.htm. Accessed 23 Aug 2017

EC (2016b) Shedding light on energy in the EU—a guided tour of energy statistics-2016 edition. European Commission. http://ec.europa. eu/eurostat/cache/infographs/energy-2016/bloc-3b.html. http:// europa.eu/rapid/press-release_IP-16-4009_en.htm. Accessed 23 August 2017

EP (2013) Energy roadmap 2050. European Parliament resolution of 14 March 2013 on the Energy roadmap 2050, a future with energy (2012/2103 (INI)). (2016/C 036/11 ) OJ C 36, 29.1.2016, p. $62-$
76. http://eur-lex.europa.eu/legal-content/EN/TXT/PDF/?uri= CELEX:52013IP0088\&from=PL Accessed 23 August 2017

ERO (2016) Thermal power in numbers-2015. Warsaw: Energy Regulatory Authority (Urząd Regulacji Energetyki)

EU (2016) EU energy in figures. Statistical pockebook 2016. Energy. Publications Office of the European Union, Luxembourg

Gawlik L (2017) Opportunities and threats for hard coal mining in Poland. Humanities and Social Sciences 24:3

GUS (2009-2016). Energy statistics (Gospodarka paliwowoenergetyczna) GUS (central statistical office), Warsaw, issue from years 2009-2016

GUS (2016) Energy statistics in 2014-2015 years. (Gospodarka paliwowo-energetyczna w latach 2014-2015). GUS (Central Statistical office), Warsaw

IEA (2016) The medium-term renewables market report, market analysis and forecasts to 2021, International Energy Agency, Paris

IED (2010) Industrial Emission Directive. Directive 2010/75/EU of the European Parliament and of the council of 24 November 2010 on industrial emissions (integrated pollution prevention and control) (O. J L334/17, 17.12.2010)

Lorenz U Ozga-Blaschke U (2016) The impact of changing market conditions on the forecasted prices of hard coal in international trade. (Wpływ zmieniających się warunków rynkowych na prognozowane ceny węgla kamiennego w handlu międzynarodowym) Przegląd Górniczy 5:3-12

MCP (2015) Medium Combustion Plants Directive. Directive (EU) 2015/ 2193 of the European Parliament and of the council of 25 November 2015 on the limitation of emissions of certain pollutants into the air from medium combustion plants (O.J L 313/1, 28.11.2005)

ME (2016) Framework power engineering program 200+. Revitalization and reconstruction of power plants based on 200 MW blocks. Ministry of Energy, (internal materials)

Mlynarski T, Ruszel M, Szurlej A (2017) Energy transformation concept in: energy policy transition - perspective of different states. Ignacy Lukasiewicz Energy Policy Institute, Rzeszow. (in print)

PEP (2009) Energy Policy of Poland until 2030. (Polityka energetyczna Polski do 2030 roku). Ministry of Economy, Warszaw

Project (2017) Program for the hard coal mining sector in Poland - draft. Ministry of Energy, Warsaw

PSE (2017) Polish Grid Company (Polskie Sieci Elektroenergetyczne SA). http://www.pse.pl/index.php?modul=8\&y=2015\&m=12\&id $\mathrm{rap}=212$. Accessed 20 June 2017

Report (2016) Report 2016 of the Domestic Electric Grid (Raport 2016 KSE) http://www.pse.pl/index.php?did=3335. Accessed 18 August 2017

Szczerbowski R (2016) The forecast of Polish power production sector development by 2050 - coal scenario (Prognoza rozwoju polskiego sektora wytwórczego do 2050 roku - scenariusz węglowy) Polityka Energetyczna - Energ Policy J 19, 3:5-18

Szuflicki M, Malon A, Tymiński M (eds) (2017) Balance of mineral deposits in Poland as on 31 XII 2016. Polish Geological Institute National Research Institute. State Geological Service, Warsaw 